\title{
DEVELOPMENT OF LAND TRANSPORT CONNECTIONS BETWEEN ASIA AND EUROPE AND THEIR POSSIBLE IMPACT ON VECTOR INTRODUCTION INTO EUROPEAN COUNTRIES
}

\author{
Aleksandra Gliniewicz \\ National Institute of Public Health - National Institute of Hygiene, Department of Health Promotion \\ and Chronic Diseases Prevention, Warsaw, Poland
}

\begin{abstract}
The possibility of transfer of several organisms - disease vectors by land transportation Asia - Europe corridors into European countries is discussed. In Europe most alien species are of Asiatic origin. Trade and exchange of goods have developed very intensively for the beginning of the XXI century between Asia and European Union countries both by sea and land routes. Road and railway connections shorten the time of goods' transport from China to Europe to 10,5 - 12 days. Shorter travel time and increased intensity of trade can increase the risk of introducing vector organisms from Asian countries to Europe. Existing legal international regulations (International Health Regulations, IHR) provide procedures to protect goods and persons against the carriage of organisms - vectors at every stage of transport and travel. Mass passenger and car traffic at border crossing points increase the likelihood of vector organisms entering as random stowaways; therefore it is proposed to intensify educational activities to make people aware of the danger posed by the transport of alien species of arthropods and what preventive actions to take. Unloading goods in a transit country (such as Poland) may take place at a transshipment center located near the border or inland. It is postulated to introduce a $400 \mathrm{~m}$ vector monitoring zone around both.
\end{abstract}

Key words: disease vectors, New Silk Road, Asia-Europe trade exchange

\section{STRESZCZENIE}

Przedstawiono możliwości przenikania organizmów - wektorów chorób poprzez lądowe korytarze transportowe łączące Azję z Europą do państw europejskich. W Europie większość gatunków obcych jest pochodzenia azjatyckiego. Wymiana handlowa pomiędzy krajami Azji i Unii Europejskiej od początku XXI w zaczęła się intensywnie rozwijać. System połączeń kolejowych i drogowych skrócił czas transportu towarów z Chin do Europy do 10,5 - 12 dni. Skrócenie czasu podróży i intensyfikacja wymiany towarowej może wpłynąć na zwiększenie ryzyka introdukcji organizmów wektorowych przenoszących choroby. Aktualne międzynarodowe przepisy prawne (International Health Regulations, IHR) zapewniają ochronę towarów i osób przed możliwościami przeniesienia wektorów na każdym etapie transportu towarów i podróży. Intensywny ruch osobowy i samochodowy na lądowych przejściach granicznych może zwiększyć prawdopodobieństwo przeniesienia organizmów wektorowych jako przypadkowych „pasażerów na gapę”. Dlatego też proponuje się zintensyfikowanie edukacji, aby ludzie byli świadomi niebezpieczeństwa, jakie niesie za sobą przeniesienie obcego gatunku stawonoga i jakie należy przedsiębrać środki zaradcze. Przeładowywanie towarów w kraju tranzytowym (tak jak np. w Polsce) może odbywać się w centrach przeładunkowych zlokalizowanych na granicy lub wewnątrz kraju. Proponuje się wyznaczenie $400 \mathrm{~m}$ strefy monitoringu wektorów wokół obu rodzajów centrów.

Słowa kluczowe: wektory chorób, Nowy Jedwabny Szlak, wymiana handlowa Azja - Europa

\section{INTRODUCTION}

Conquering new areas is an evolutionary phenomenon of many species. Humans have played a significant role in this process. When people changed the place of their residence, together with them and their belongings moved all organisms on their bodies, clothes, and movables. This process become more dynamic in the years of globalization, when more and more people moved because of economic, touristic and safety reasons, and also goods exchange become more intensive [13, 38]. According to Roques et al. [26] in the pre-industrial era in the Europe appeared 1-2- new species of invertebrates/year; in the period $1900-1950$

Corresponding author: Aleksandra Gliniewicz, National Institute of Public Health - National Institute of Hygiene (NIZP-PZH), Department of Health Promotion and Chronic Diseases Prevention, 24 Chocimska str., 00-791Warsaw, Poland, phone: +48 22 5421331, e-mail: agliniewicz@pzh.gov.pl

(C) Copyright by the National Institute of Public Health - National Institute of Hygiene 
there were about 6 new species; in the years 1975 2000 - there were 13 new invertebrate species per one year, respectively. Increase of prosperity influences positively a development of transport infrastructure: building national and international roads, railway connections, water channels. They can create gates for invasive species to grasp new territories. It was found, that increase of Gross Domestic Product Brutto (influenced by international trade and exchange of goods) was correlated with richer fauna of spiders, plants, birds and mammals which colonize these countries [16]. In Europe the most alien species are of Asiatic origin $-29.3 \%[26,38]$. It was stated that $45 \%$ of them are pests of medical, veterinary or economic importance.

Because trade and exchange of goods have developed very intensively since the beginning of the XXIst century between Asia and European Union countries, it would be interesting to analyze capabilities of transfer of several organisms - disease vectors by land transportation routes (railway or car transport).

\section{EUROPA - CHINA TRADE PAST AND PRESENT}

Overland trade between China and Europe dates back more than two millennia. The Silk Road carried not only silk and could be highly profitable. At different times, oases along the routes - for example Khiva, Bukhara, Samarkand - were amongst the largest cities in the world. The destruction of the overland trade was caused in times when Portuguese sailors discovered the sea routes from Europe to Asia round the Cape of Good Hope around 1500. For the next 500 years, sea was the dominant mode of transport between Europe and East Asia. In the 20th century several rail links were constructed in Asia, but none was a significant carrier of China-Europe freight. The most important was the Trans-Siberian railway built by Russia between 1891 and 1905 [22].

Economic growth in countries of Europa and Asia in XX and XXI century has been accompanied by an increase in goods exchange and in demand for transport services by air, sea, rail and road. Air transport is the most expensive; on the other hand maritime transport is much cheaper but it takes long time ( $35-45$ days). Development a rail and road links from China and other Asiatic countries aims to construct transport cheaper than by planes and faster than by sea way [10, 22].

The value of goods transported by rail from China to European Union increased between 2011 and 2016 up to $194.6 \%$, while decreased by maritime and air transport. Since 2011 regular services were established on railway routes between several Chinese and European cities (Table 1) [33].
Table 1. Transport connections developed in recent years between China and Europe

\begin{tabular}{|l|r|r|r|}
\hline Route & $\begin{array}{l}\text { Length } \\
(\mathrm{km})\end{array}$ & $\begin{array}{l}\text { Duration } \\
(\text { days })\end{array}$ & Rail/road \\
\hline Souhou - Warsaw & 11,200 & 18 & rail \\
\hline Chengdu - Lódź & 9,826 & 10.5 & rail \\
\hline Zhengzou - Hamburg & 10,124 & $19-20$ & rail \\
\hline Xianmen - Warsaw & 8,500 & 12 & road \\
\hline
\end{tabular}

Source: Euro-Asian trade flows, in: Euro-Asian Transport Linkages, Operationalisation of inland transport between Europe and Asia: 32 - 101, UNECE, New York and Geneva 2019, modified

In 2017 China and 68 countries signed the agreement about renewal a land transport route called "New Silk Road". It will pass through Middle Asiatic countries, Kazakhstan, Russia, Belarus, Poland to West Europa countries [28, 39]. It is planned that in 2020 about 5,000 container trains will run on the route Europa - China - Europa per year. In October 2019 socio - economic media [21] informed about opening a road connection between China and Poland. The time for a 24-tonnes truck to pass this rout is about 12 days (Table 1). In Table 2 there are listed several categories of commodity in Europe - Asia trade exchange; many of them were transported by rail and road routes because of short time of journey.

Table 2. Selected categories of goods in Europe - Asia trade exchange. Relative intensity of transport of good category in the direction Europe - Asia or Asia - Europe is showed by number of "+"

\begin{tabular}{|l|c|c|}
\hline Category of commodity & $\begin{array}{c}\text { Europe } \\
- \text { Asia } \\
\text { direction }\end{array}$ & $\begin{array}{c}\text { Asia }- \\
\text { Europe } \\
\text { direction }\end{array}$ \\
\hline Live animals & +++ & + \\
\hline Animal originated products & ++ & +++ \\
\hline Trees, plants, ornamental plants & +++ & + \\
\hline Vegetables, roots, edible & ++ & +++ \\
\hline Fruits and nuts, citrus, melons & + & +++ \\
\hline Coffee, tea, spices & ++ & +++ \\
\hline Oil seeds, grains, medicinal plants & ++ & +++ \\
\hline Prepared animal fodder, residues, wastes & ++ & ++ \\
\hline Rubber, rubber products & + & ++ \\
\hline Miscellaneous manufactured articles & + & +++ \\
\hline Textiles clothing & + & +++ \\
\hline Textiles, tapestries, woven fibers & + & +++ \\
\hline Stone, plaster, cement, asbestos & ++ & +++ \\
\hline Aluminum, nickel, zinc, tin & + & ++ \\
\hline Electronic articles & + & + \\
\hline Source: Trade & + & + \\
\hline
\end{tabular}

Source: Trade flows between Europe and Asia, in: Euro-Asian Transport Linkages,

Operationalisation of inland transport between Europe and Asia: 197 - 287, UNECE, New York and Geneva 2019, modified 


\section{RISK OF "UNEXPECTED PASSENGERS" - DISEASE VECTORS TRANSFER THROUGH LAND TRANSPORT CONNECTIONS FROM ASIA TO EUROPE}

The majority of important disease vectors are active vectors - they can insert pathogen into human organism by direct damage of human skin by biting, stinging, because a pathogenic organism can be present or develop inside the vector. Important features of active vectors are: possibility of changing the host, anthropo/zoophility, sucking blood several times. Mosquitoes and ticks are examples of active vectors.

The other group are passive (or mechanical) vectors - they carry pathogens on surface of their bodies or in digestive tract. Their presence in the environment close to people and mobility can pose a threat to human health. Non-bloodsucking flies and cockroaches appearing in mass numbers close to people, penetrating different environments, having wide spectrum of food can mechanically contaminate food or surfaces by pathogenic microorganisms.

\section{Mosquitoes}

Although trade and travel are important in the introduction and subsequent dispersion of mosquitoes, climate suitability is also believed to have been an important factor. Warm seasonal and annual temperatures and ample rainfall in Europe offer conductive climatic conditions for Aedes albopictus - one of the world's most invasive vector. The introduction and geographical expansion of the vector has coincided with favorable climatic conditions in France, the Balkans, the eastern coasts of Spain and the Adriatic Sea, the Benelux countries and western Germany [27, 29]. Considering transport corridors Asia - Europe, the freight exchange between countries of these two continents is growing from year to year. There are existed and planned great hubs on ground crossings where containerized goods had been reloaded to transport further by trans-European routes $[22,28]$. As Thomas et al. [32] simulated, there can be an increasing risk of introducing of Aedes albopictus mosquito when climatic suitability is higher and freight via train is increasing. Such a situation can be created on hubs at South - East EU border, where ground crossings (with intensive commodity flow: Bulgaria - Turkey, Romania - Ukraine) lay in suitable for Ae. albopictus climatic zone. However, some other parts of Europe that have not yet been invaded by this vector can be climatically suitable for $A$. albopictus and lay on the main transport routes from East to West. Several localities in Poland along the transportation corridors from East to West could be an example of regions where suitable conditions for a Tiger Mosquito could be considered; in such towns as: Wrocław, Katowice, Łódź, Poznań average summer months temperature could be high enough to allow development of 2 generations of Aedes albopictus mosquitoes and winter temperatures in these towns in recent years oscillated around $2-3^{\circ} \mathrm{C}$, which could be enough to overwintering eggs of this mosquito [29]. Figure 1. shows a system of international and national roads and railway connections in Poland important for transit goods in East - West direction. The main logistic centres are: Brest/Terespol and Malaszewicze on the Poland - Belarus border; Medyka/Żurawica on the Poland - Ukraine border; inland logistic centers are: Warsaw, Łódź, Sławków (Katowice nearby), Wroclaw, Poznań.

Trade companies work on shorten time of delivery goods from Asia - now it is between 10.5 and 21 days (Table 1). In this time adults mosquitoes can survive and immature stages can develop in appropriate conditions (humidity and temperature).

Table 2 presents categories of commodities transported from China to Europe - among them are plans - several of them are transported in water or moist substrate. This enhance the probability of transportation of eggs or larvae of mosquitoes. One of the way of introducing Aedes albopictus to European region (Benelux countries) was an import of Lucky Bamboo plants which were transported in small containers with water (larvae of mosquitoes were developed in them). Different way was export of used tires and then transported from sea ports via car transport across West European countries [29].

To sum up, considering trade routes and conditions, the freight transport way from Asia to Europe could play a role in introduction $A e$. albopictus into several European territories, both where this mosquito is establish by now and also new territories with suitable climatic conditions.

Data from the literature $[14,15,27]$ showed that other invasive Aedes species in North and Central Europe do not find suitable environmental conditions to expand till now, even the introduction cases have taken place. Anopheles mosquitoes could accompanied mostly living beings: travelling people or transported animals. Generally, the inflow of alien mosquito species must be continuous or at least multiple to establish population in a new area [17]. However, the changing climatic conditions should be taken into account: several too cold territories now can be warmer and more suitable in the future for mosquitoes. 
Figure 1. A system of international and national roads and railway connections in Poland important for transit trade in East - West direction.

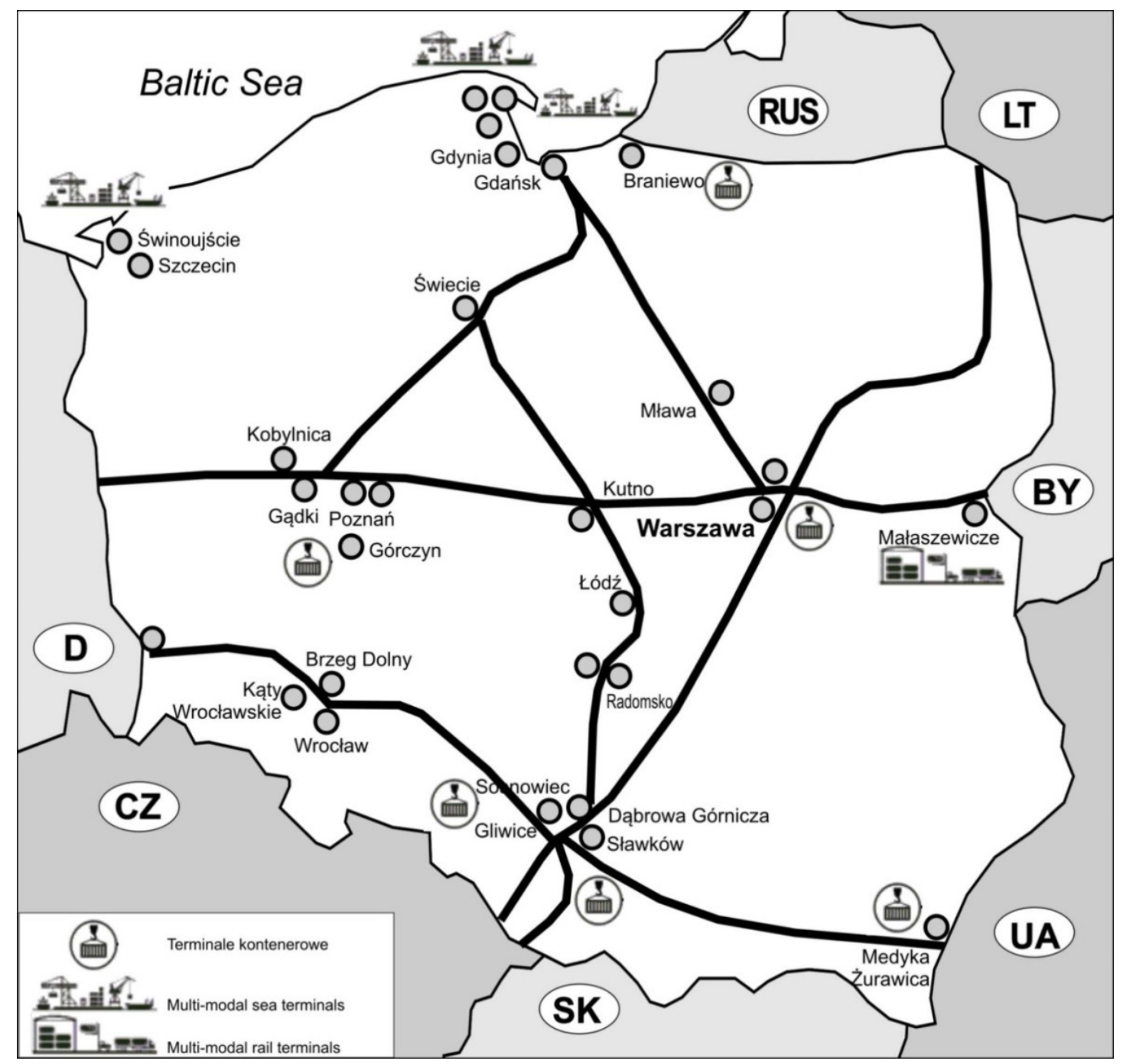

(Source: www.agatstudio.waw.pl)

\section{Ticks}

Most of ticks can reach new territories on their host bodies. Migratory birds can be the source of introducing ticks; but mostly these arthropods do not build stable populations when are transported long distance between continents. Bigger chance to establish in a new environment have ticks who were transported on birds at shorter distances - for example moving from East to West or South to North Europe on bird of one species changing the territory in Autumn or Spring $[11,14]$. The tick Ixodes ricinus, effective vector of Lyme borreliosis is present almost in the whole Europe [20].

Livestock transported into Europa countries from East - South territories (South Europe and Asia) could be infested by Hyalomma ticks [15]. Living animals is one of the commodity category transported from Asia to Europe and there is a possibility to transport ticks on them as well. - Despite of a danger to introduce new tick species animal transports should be carefully inspected and veterinary checked before transportation.
People coming back from holidays and their pets can be the carriers of ticks living in south and east-south territories of Europe: Hyalomma spp., Ripicephalus spp. [11, 19]. Ripicephalus sanguineus tick is of Mediterranean and Black Seas Basins origin. It was found on dogs which had been taken for holidays in south and then carried ticks when they returned back to their homes $[14,19]$.

\section{Fleas}

Fleas can extend territory with their hosts together. Many of them live on specific animal species and occur where they live. The changing of living area by an animal specimen causes that all external parasites go with him. This is true for people and their belongings - they can be also carriers of external parasites [12, $37,38]$.

Several flea species, among them the oriental rat flea - Xenopsylla cheopis (which is the vector of Yersinia pestis, a plague causative agent) parasitize on 
rats, so the ratproofing and rat control of transported goods are important actions which ought to be undertaken to prevent dissemination of fleas.

\section{Cockroaches}

Cockroaches are common in the whole world except arctic areas. There are species present at human dwellings and lived outside. They can invade means of transport like ships, aircraft, trains and are present everywhere they can find food and water. Many categories of transported commodities can serve as appropriate food and harborage for cockroaches of several species - they can travel between continents [2]. Exotic tropical species were found in Sweden (in heated greenhouses Pyenoscellus surinamensis was established), but Periplaneta australasiae, and Supella longipalpa were recorded from Czech Republic [15]. Transported goods should be carefully controlled if they are cockroach free, because these insects can survive and develop during long journey in hidden places.

\section{Flies}

There is no part of world free from flies . They are common around human settings, animal farms, food processing plants, restaurants, hotels, e.t.c. Housefly is elsewhere, so it is difficult to consider it as an invader. Many fly species are called "synantropic flies" as they are present in antropogenic environment, close to people [30].

Flies can accompany living animals in transport. Where are living animal there is manure. In this medium many species of flies can develop, so it is necessary to clean regularly animal containers and to use IGR (Insect Growth Regulators) agents for prevent development of flies. Transported animals can carry in their bodies larvae of fly species which develop in living organisms and are aliens in the new area. Such invasions can occur among tourists coming back from tropical or subtropical climatic zones as well. Among species recorded as larvae in human and animal bodies, alien in Europe, were: Cordylobia anthropophaga (Africa, Arabian Penninsula), Wohlfartia magnifica (Mediterranean area, Russia, China) [13, 15].

The procedures of insect proofing and insect control should be applied during preparing goods to transport and veterinary procedures when living animals will be transported.

\section{DISCUSSION}

Hazard of diseases caused by pathogens transported by arthropod vectors which can arise at ground crossings at East and South - East EU border should be considered taking into account the following aspects $[17,38]$ :
1. Presence of vectors infected by pathogens in the place of loading goods or starting point of journey of people.

2. Transport or journey conditions - if they allow to survive some of development form of vector .

3. Transport of vector - incidentally (little chance of introduction) or multiple (greater chance of introduction).

4. Conditions - suitable by vector organism to survive at the point of entry or not.

5. Environmental conditions in the target area - suitable for surviving or development of vector or not.

Actions undertaken to stop the invasion of alien species - vectors to the new territories according to above list of problems should be carried out at starting point of loading goods (or starting point of passenger journey), during transport, on crossing point at the border and at the terminus where commodities were unloaded. Such operations are regulated by International Health Regulations [19] and European Union $[1,4,5,6,7,8,9,23,24,25]$ and state laws $[34,35,36]$.

Vector organisms, as well as others, change and expand their area of occurrence in time. This process accelerated in the 20th and 21st centuries. This may be related to:

- globalization - intensifying trade in goods and increasing the travel of people between continents and various climate zones;

- climate change: many species find favourable conditions for living in new areas that are not yet climatically accessible to them, while the others leave areas that are becoming inappropriate for them;

urbanization of the environment, which is associated with higher temperatures in cities resulting from the intensive human economy [38]. In Western, South and lately Central Europe, the expansion of the Aedes albopictus mosquito, a vector of dengue and Chikungunya virus has been observed from the 70s. This mosquito gradually takes over areas located in France, Germany, Italy, Spain, Switzerland, Croatia, Austria and the Czech Republic. Also other mosquitoes of the genus Aedes spp., having the ability to expand beyond their original limits of occurrence colonize new areas in Europe (e.g. Aedes aegypti was the vector of Dengue causative agent DENV-1 in Madeira island in 2012) [29].

Ticks from the genera Hyalomma spp., and Ripicephalus spp., that were found in the past in the Mediterranean and Eurasian forest-steppe areas are also noted more north [11, 19]. Exotic species of cockroaches are brought to the countries of Europe along with transported goods (there are cases of their survival in heated greenhouses and hotels) [15]. 
Travelers, returning from tropical countries infected with fly larvae developing in human and animal tissues, report to doctors [13].

Existing regulations governing the exchange of goods and the movement of persons between countries are accurate and cover all aspects from the preparation of the goods to dispatch / commencement of travel by people, to reaching the final destination by the goods and people [20,39].

Crossing the border between states (in this aspect - the state border between a country bordering on the west or south-west side and a country of the European Union) is one of the stages included in legal regulations. It should be emphasized that the goods are not always unloaded at transshipment centers on the border; in Poland such centers exist in the interior of the country (Warsaw, Poznań, Łódź and Sławków near Katowice) or containers are only opened at the destination. In addition to border controls, those that take place in customs warehouses in transshipment centers play a significant role in the control of transported goods. Therefore, the proper preparation of goods for transport is even more important in the aspect of preventing arthropods - vectors from infesting them and protecting the container and goods against rodents. These types of activities are recorded in the transport documents controlled at the border crossing $[4,5]$.

Customs and sanitary regulations regarding the flow of people across borders clearly specify the control in situations of threat to public health $[18,25]$. It should be stated that actions aimed at limiting the accidental invasion of an arthropod - vector are difficult to carry out by sanitary and border services and can be burdensome for travelers. Some, despite the assumed effectiveness, cannot be carried out (e.g. passenger car, luggage, clothes). Therefore, it should be assumed that the source of vectors - stowaways at the border crossing may be passenger transport vehicles and people traveling with them. This route was confirmed in the case of the spread of the mosquito Aedes albopictus through ferry communication between the islands in the Mediterranean Sea and in places along the Sun Highway on its European coast [29]. Since it is not possible to carry out intensive eradication activities at border crossing points in passenger traffic, it would be necessary to strengthen public education so that people increase their knowledge about vector organisms and their role in transmitting diseases, their occurrence, possibilities of accidental transport and means of protection against them.

At border crossing points with significant passenger traffic or where goods are transshipped, it is reasonable to create a 400 -meter vector monitoring zone, as proposed in the International Health
Regulations [18]. Such zones should also be created in customs warehouses and transshipment centers within transit countries (e.g. in Poland). Existing provisions of law do not provide for this; one should therefore consider the legitimacy of their changes in this respect. The provisions of international law [18] and national regulations since 2005 regulate every stage of the international flow of goods and people. However, it should be taken into account that the presence of alien arthropod vectors has been signaled in many European countries since the 90s of the XX century [29, 31]. Existing legal regulations provide control over the introduction of organisms - disease vectors into European Union countries from countries bordering it. However, the problem is the spread of vectors in areas within the European Union. Control of these processes could be ensured by adequate monitoring. This requires the involvement of human resources and measures, which is why it is currently carried out at random, in some areas and only in some countries. It would be particularly needed in countries with a high transit flow of goods, such as Poland. Due to the epidemiological significance, at least the mosquito fauna should be monitored around the transshipment centers of goods on the eastern border and within the country (perhaps also here appropriate legal regulations are needed).

\section{CONCLUSIONS}

1. Vector organisms can enter new areas along with goods, in luggage or clothing of travelers, as well as a result of the expansion of acreage occurring in natural evolutionary processes.

2. Existing legal regulations provide procedures to protect goods and persons against the transport of organisms - vectors at every stage of transport and travel.

3. Expansion of Asia-Europe transport routes and shortening travel time can increase the risk of introducing vector organisms from Asian countries to Europe

4. Mass passenger and car traffic at border crossing points increases the likelihood of vector organisms entering as random stowaways, therefore it is proposed to intensify educational activities to make people aware of the dangers posed by the transport of alien species of arthropods and what preventive actions to take.

5. Unloading goods in a transit country (such as Poland) may take place at a transshipment center located near the border or inland. It is postulated to introduce a $400 \mathrm{~m}$ vector monitoring zone around both.

6. Such a zone should also be taken into account at border crossings with heavy passenger and car traffic. 


\section{Vectors do not respect political borders!}

\section{Conflict of interest}

The author declares no conflict of interest.

\section{Acknowledgments}

This work was supported by the EU Project No W112/ HP3/2018 and statutory financial help of the National Institute of Public Health-National Institute of Hygiene (NIZP-PZH) in Warsaw. I thank you very much Dr Janusz Janiec (Department of Epidemiology at NIZP$P Z H)$ for the inspiration and giving possibility to work on this subject.

\section{REFERENCES}

1. Agreement on the Application of Sanitary and Phytosanitary Measures (WTO GATT 1994). OJ L 1994;336/40.

2. Appel A: Blattella and related species. In: Understanding and controlling the German Cockroach. In: Rust M, Owens $J$, Reierson D. (eds), Oxford University Press 1995;1-20

3. Caminade C, Medlock J, Ducheyene E, McIntyre K.M, Leach S, Baylis M, Morse A: Suitability of European climate for the Asian tiger mosquito Aedes albopictus: recent trends and future scenarios. J. R. Soc. Interface 2012;9:2708-2717.

4. Commission Implementing Decision (EU) 2017/253 of 13 February 2017 laying down procedures for the notification of alerts as part of the early warning and response system established in relation to serious cross-border threats to health and for the information exchange, consultation and coordination of responses to such threats pursuant to Decision No 1082/2013/EU of the European Parliament and of the Council (Text with EEA relevance). OJ L 37, 14.2.2017, p. 23-27

5. Commission Implementing Regulation (EU) 2018/1882 of 3 December 2018 on the application of certain disease prevention and control rules to categories of listed diseases and establishing a list of species and groups of species posing a considerable risk for the spread of those listed diseases (Text with EEA relevance.). OJ L $308,4.12 .2018$, p. 21-29

6. Commission Regulation (EC) No 136/2004 of 22 January 2004 laying down procedures for veterinary checks at Community border inspection posts on products imported from third countries (Text with EEA relevance),OJ L 21, 28.1.2004, p.11-23

7. Council Directive 91/496/EEC of 15 July 1991 laying down the principles governing the organization of veterinary checks on animals entering the Community from third countries and amending Directives 89/662/ EEC, 90/425/EEC and 90/675/EEC. OJ L 268, 24.9.1991, p. 56-68

8. Council Directive 97/78/EC of 18 December 1997 laying down the principles governing the organisation of veterinary checks on products entering the Community from third countries. OJ L 24, 30.1.1998, p. 9-30
9. Decision No 1082/2013/EU of the European Parliament and of the Council of 22 October 2013 on serious cross-border threats to health and repealing Decision No 2119/98/EC Text with EEA relevance. OJ L 293, 5.11.2013, p. $1-15$

10. Euro-Asian trade flows. In: Euro-Asian Transport Linkages, Operationalisation of inland transport between Europe and Asia:, UNECE, New York and Geneva 2019;32-101.

11. Gliniewicz A., Karbowiak G., Mikulak E., SuperganMarwicz M., Królasik A., Myślewicz J.: Impact of Climate Change on Medically Important Ticks in Europe and Their Control. In: Climate Change Impacts on Urban Pests. Partho Dang (ed.), CABI International 2017;111-126

12. Gratz N: The flea - borne diseases. In: Gratz N. (ed.) Vector-and Rodent-borne Diseases in Europe and North America: Cambridge Univ. Press 2006;78 - 82.

13. Gratz $N$ : Vector-borne disease problems associated with introduced vectors in Europe. In: Gratz N.( ed.): Vector-and Rodent-borne Diseases in Europe and North America: Cambridge Univ. Press. 2006:156-158.

14. Gratz N: Factors augmenting the incidence, prevalence and distribution of vector-borne diseases in Europe. In: Gratz N. (ed.), Vector-and Rodent-borne Diseases in Europe and North America. Cambridge Univ. Press. 2006; $159-160$.

15. https://ecdc.europa.eu/en/disease-vectors/facts, access $01-05.06 .2019$

16. Hulme P, Bacher S, Kenis M, KlotzS, Kuehn I, Minchin $D$, Nentwig $W$, Olenin S, Panov V, Pergl J, Roques A, Sol $D$, Solarz W, Vila M: Grasping at the routes of biological invasions: a framework for integrating pathways into policy. J App Ecol 2008;45: 403-414.

17. Hulme P: Trade, transport and trouble: managing invasive species pathways in an era of globalization. J. App. Ecol. 2009;46: 10-18.

18. International Health Regulations. $3^{\text {rd }}$ edition, WHO, Geneva 2016.

19. Nowak-Chmura M.: Fauna kleszczy (Ixodida) Europy Środkowej. [Tick Fauna of the Middle European Region]. Wyd. N. Uniw. Ped. Kraków 2013. (in Polish)

20. PańczukA., Tokarska-RodakM., PlewikD., Paszkiewicz $J .:$ Tick exposure and prevalence of Borrelia burgdorferi antibodies among hunters and other individuals exposed to vector ticks in eastern Poland. Rocz Państw Zakl Hig 2019;70(2):161-168; doi:10.32394/rpzh.2019.0066

21. Polityka press service, $2019,42: 35$.

22. Pomfret R.: The Eurasian Land Bridge. The Role of Service Providers in Linking the Regional Value Chains in East Asia and the European Union, ERIADP-2018-01.

23. Regulation (EC) No $853 / 2004$ of the European Parliament and of the Council of 29 April 2004 laying down specific hygiene rules for food of animal origin, OJ L 139, 30.4.2004, p. 55-205

24. Regulation (EU) No 576/2013 of the European Parliament and of the Council of 12 June 2013 on the non-commercial movement of pet animals and repealing Regulation (EC) No 998/2003 Text with EEA relevance, OJ L 178, 28.6.2013, p. 1-26. 
25. Regulation (EU) 2016/399 of the European Parliament and of the Council of 9 March 2016 on a Union Code on the rules governing the movement of persons across borders (Schengen Borders Code), OJ L 77, 23.3.2016, p. $1-52$.

26. Roques A, Rabitch $W$, Rasplus J, Lopez-Vaamonde C, Nentwing $W$, Kenis $M$ : Alien Terrestrial Invertrebrates of Europe. https:/www.researchgate.net/publication/225878786_Alien_Terrestrial_Invertebrates_of_ Europe, (Access 29.09.2019)

27. Semenza J, Suk J: Vector-borne diseases and climate change: a European perspective. FEMS Microbiol. Letters 2018, 365: 1-9.

28. Silk Road Economic Belt, in: Euro-Asian Transport Linkages, Operationalisation of inland transport between Europe and Asia: 127 - 128, UNECE, New York and Geneva 2019.

29. Scholte E-J, Schaffner F: Waiting for the tiger: establishment and spread of the Aedes albopictus mosquito in Europe. In: Emerging pests and vector-borne diseases in Europe In: Takken W. and Knols B. (eds), Wageningen Ac. Publishers, 2007; Vol.1: 241-260.

30. Smallegange $R$, Otter $C$ : Houseflies, annoying and dangerous, in: Invasions of vector-borne diseases driven by transportation and climate change. In: Emerging pests and vector-borne diseases in Europe Takken $W$. and Knols B. (eds.), Wageningen Ac. Publishers, 2007; Vol.1: 281- 292.

31. Tatem A.J, Rogers D.J, Hay S.I: Global Transport
Networks and Infectious Disease Spread, Adv. Parasitol. 2006;62:293-343.

32. Thomas S.M. Tjaden N.B, van den Bos S, Beierkuhnlein $C$ : Implementing Cargo Movement into Climate Based Risk Assessment of Vector-Borne Diseases, Int J Environ. Res. Public Health 2014;11:3360-3374.

33. Trade flows between Europe and Asia. In: Euro-Asian Transport Linkages, Operationalisation of inland transport between Europe and Asia. UNECE, New York and Geneva 2019;197-287.

34. Ustawa $\mathrm{z}$ dn. 27.08.2003 o weterynaryjnej kontroli granicznej. Dz.U. 2003 nr 165 poz. 1590.

35. Ustawa $z$ dn. 1103.2004 o ochronie zdrowia zwierząt oraz zwalczaniu chorób zakaźnych zwierząt. Dz.U 2004 nr 69 poz. 625.

36. Ustawa $\mathrm{z}$ dn. 05.12.2008 o zapobieganiu oraz zwalczaniu zakażeń i chorób zakaźnych u ludzi. Dz.U. 2008 nr 234 poz. 1570.

37. WHO. Vector Surveillance and Control at Ports, Airports and Ground Crossings. WHO, Geneva, Switzerland 2016.

38. Weijden $W$, Marcelis $R$, Reinhold $W$ : Invasions of vectorborne diseases driven by transportation and climate change, In: Emerging pests and vector-borne diseases in Europe. Takken $W$. and Knols B. (eds.), Wageningen Ac. Publishers 2007; Vol.1: 439- 463.

39. www.rynekinfrastruktury.pl, (Access 27.10.2019)

Received: 08.11.2019

Accepted: 02.12.2019 